\title{
Perilaku Siswa yang Tidak Dikehendaki (Off Task Behavior) dan Penanganan Konselor
}

\author{
Ridni Eliza ${ }^{1}$, Neviyarni ${ }^{2}$ \\ Prodi Bimbingan dan Konseling Universitas Negeri Padang 1 \\ elizaridni@gmail.com, neviyarni.suhaili911@gmail.com
}

First received:

01 Oktober 2020
Revised:

02 Nobember 2020
Final Accepted:

20 November 2020

\begin{abstract}
The purpose of this research was to describe the forms, causes, counselor handling and counselor in dealing with barriers off task behavior of student in Ash - Shidiiqi Islamic Primary School Jambi. The methods used to collect the data are interviews, observation, and documentation. The subject in this research is the headmaster, 2 (two) counselors, 7 (seven) teachers, 3 (three) seubject teaachers, and 7 (seven) students who have off task behavior. The results showed that the off task behavior of students going on Ash - Shidiiqi Islamic Primary School Jambi, around the class, talking with friends, play stationery such as pen, pencil, eraser, or ruler, play or throw paper, do not pay attention to the teacher's explanation, put the head on the table, make a noise, climbed to the top of the seat, out of the class, joking with friends, drawing on paper, scribble table, opened another textbooks, do homework. The causes of student conduct off task behavior consists of internal factors and external factors. Internal factors include the adaptation of school and difficulty in learning. While external factors that underlie the emergence of off task behavior of student is the influence of friends and lack of attention from the teacher. There are various kinds of treatment used by counselor, which are reprimand or warned by giving advice, in addition to dealing with off task behavior counselor collaborate with classroom teachers and subject teachers to apply operant conditioning by using the reinforcement and punishment techniques. Barriers faced counselor is limited provosion of counseling.
\end{abstract}

Keywords: off task behavior, counselor handling

\section{Abstrak}

Tujuan penelitian ini adalah mendeskripsikan tentang bentuk-bentuk, faktor penyebab, penanganan konselor dan hambatan yang dialami konselor dalam menangani perilaku off task siswa di SDIT Ash - Shidiiqi Jambi. Metode yang digunakan untuk mengumpulkan data adalah wawancara, observasi, dan dokumentasi. Subyek dalam penelitian ini adalah kepala sekolah, 2 (dua) konselor, 7 (tujuh) guru kelas, 3 (tiga) guru mata pelajaran, dan 7 (tujuh) siswa yang memiliki perilaku off task. Hasil penelitian menunjukkan bahwa bentuk perilaku off task siswa yang terjadi di SDIT Ash - Shidiiqi Jambi yaitu berjalanjalan di dalam kelas, berbicara dengan temannya, bermain alat tulis seperti pensil, pulpen, penghapus atau penggaris, bermain kertas, tidak memperhatikan penjelasan guru, meletakkan kepala di atas meja, membuat gaduh, naik ke atas kursi, keluar masuk kelas, bercanda dengan temannya, menggambar di kertas, mencoret-coret meja, membuka buku pelajaran lain, mengerjakan PR. Penyebab siswa melakukan perilaku off task terdiri dari faktor internal dan faktor eksternal. Faktor internal meliputi adaptasi sekolah 
dan kesulitan dalam pelajaran. Sedangkan faktor eksternal yang mendasari munculnya perilaku off task siswa yaitu pengaruh dari teman dan kurangnya perhatian dari guru. Ada berbagai macam penanganan yang dilakukan oleh konselor, diantaranya adalah menegur atau mengingatkan dengan memberi nasihat, selain itu untuk menangani perilaku off task siswa konselor berkolaborasi dengan guru kelas dan guru mata pelajaran menerapkan teori pengkondisian operan dengan menggunakan teknik penguatan dan teknik hukuman. Hambatan yang dihadapi konselor adalah keterbatasan pemberian layanan konseling secara langsung dan masih sulitnya mengontrol sikap siswa SD karena belum memiliki keajegan dan masih butuh bantuan dari guru dan orang tua

Kata Kunci: perilaku off task, penanganan konselor

\section{PENDAHULUAN}

Belajar merupakan semua aktivitas mental atau psikis yang berlangsung dalam interaksi aktif dalam lingkungan, yang menghasilkan perubahan-perubahan dalam pengelolaan pemahaman. Agar dapat mencapai hasil belajar yang baik, maka harus memperhatikan faktor-faktor baik dari dalam diri individu maupun dari luar.Salah satu faktor yang mempengaruhi keberhasilan dalam belajar yaitu faktor dari dalam diri anak atau individu yang belajar, terutama yang terkait dengan perilaku.

Pada umumnya terdapat beberapa masalah perilaku siswa dalam proses belajar di kelas. Ada perilaku siswa dalam situasi belajar di kelas yang tidak dikehendaki kemunculannya, perilaku tersebut biasa disebut dengan off task behavior.Beberapa ahli menggambarkan perilaku siswa yang tidak dikehendaki (off task behavior) di kelas diantaranya perilaku impulsive (impulsiveness), tidak memperhatikan (inattention), tidak menyelesaikan tugas (noncompletation of task), meninggalkan tempat duduk (out of seat), berbicara tanpa permisi (talking without permission), tidak mempunyai motivasi belajar (unmotivated to learn), tidak siap mengikuti kegiatan di kelas (unprepared for class) dan mengganggu (disruptive). Jika perilaku yang tidak dikehendaki ini terus menerus dilakukan oleh siswa ketika proses belajar-mengajar berlangsung, maka dapat mengakibatkan pada kegagalan akademik, seperti rendahnya prestasi siswa terhadap pelajaran, tinggal kelas dan bahkan tidak lulus dalam ujian akhir. (Sparzo \& Poteet, dalam Sukiman 2005)

Begitu juga menurut David \& Nicholas (2011:29) Perilaku siswa yang tidak dikehendaki dapat berdampak pada pembelajaran siswa di berbagai tingkat. Pada tingkat individu proses belajar siswa tersebut mungkin terbengkalai saat ia tidak berhasil melatih keterampilan yang diajarkan di kelas. Pada tingkat kelompok, gangguan yang mungkin terjadi ketika siswa keluar dari tempat duduk atau agresif untuk off task, yang selanjutnya menyebabkan lebih banyak siswa memilih untuk off task dan mungkin pada akhirnya menghasilkan sebagian kecil pelanggaran serius terhadap kelas dan peraturan sekolah. 
Sekolah memiliki tanggung jawab yang besar membantu siswa agar berhasil dalam belajar.Untuk itu di sekolah layanan bimbingan dan konseling sangat penting untuk dilaksanakan guna membantu siswa mengatasi berbagai masalah yang dihadapinya. Bimbingan dan konseling sebagai suatu layanan yang dimaksudkan untuk proses pemberian bantuan yang dilakukan melalui wawancara konseling (face to face) oleh seorang ahli (disebut konselor) kepada individu yang sedang mengalami sesuatu masalah (disebut konseli). Melalui layanan bimbingan dan konseling diharapkan siswa dapat mengatasi masalah yang dihadapi dan memanfaatkan berbagai potensi yang dimiliki sehingga dapat memahami dirinya sendiri untuk mencapai perkembangan yang optimal.

\begin{tabular}{ccc}
\multicolumn{2}{c}{ Berdasarkan hasil studi } \\
pendahuluan pada tanggal & $27-28$
\end{tabular}
Februari dan 3-4 Maret 2020 serta 24-26 Maret di SDIT Ash - Shidiiqi Jambi, peneliti melakukan kegiatan observasi di 7 kelas sesuai dengan rekomendasi dari konselor sekolah yaitu kelas $1 \mathrm{~B}, 2 \mathrm{~B}$, $3 \mathrm{C}, 4 \mathrm{C}, 5 \mathrm{~B}, 5 \mathrm{C}, 6 \mathrm{C}$, rata-rata 1 sampai 3 siswa dari kelas tersebut melakukan perilaku yang tidak dikehendaki saat pembelajaran berlangsung, siswa pertama memiliki frekuensi perilaku antara 6-8 kali, siswa kedua memiliki frekuensi perilaku antara 7-9 kali, dan siswa ketiga memiliki frekuensi perilaku selama 8-10 kali. Adapun perilaku yang dilakukan sebagai berikut : mencari perhatian dan menggganggu teman di sekitarnya dengan mengajak ngobrol di luar materi pembelajaran, bermain mainan, tidak bisa diam di tempat duduknya, berbuat usil kepada temannya (melempar gulungan kertas), melamun, keluar masuk kelas saat kerja kelompok. Perilaku tersebut muncul hampir di semua mata pelajaran. Adapun dampak dari perilaku tersebut adalah siswa tidak dapat menjawab pertanyaan yang diberikan oleh guru,terlambat mengumpulkan tugas, bahkan ada juga siswa yang tidak dapat mengerjakan tugas. Menurut hasil wawancara dengan guru mata pelajaran dan guru kelas, hal tersebut sangat mengganggu karena berpengaruh terhadap keberhasilan pembelajaran siwa itu sendiri dan juga siswa lain. Idealnya setiap siswa bisa mencapai keberhasilan pembelajaran $75-85 \%$, akan tetapi ada 13 siswa yang hanya bisa mencapai 35$40 \%$ saja, hal ini tentunya berpengaruh pada prestasi siswa.

Berdasarkan fenomena tersebut peneliti berkeinginan untuk melakukan penelitian tentang "Perilaku Siswa yang Tidak Dikehendaki (Off Task Behaviour) dan Penanganan Konselor di SDIT Ash Shidiiqi Jambi", yang bertujuan untuk mengetahui bentuk-bentuk perilaku siswa yang tidak dikehendaki, faktor-faktor penyebab perilaku siswa yang tidak dikehendaki, dan hambatan yang ditemukan konselor dalam penanganan terhadap perilaku tersebut.

Gibson \& Mitchell (dalam Nursalim, 2011) mengemukakan beberapa peran utama konselor di sekolah dasar, yakni sebagai konselor, konsultan, koordinator, agen perubahan, asesor, pengembang karir, dan agen pencegahan.Dalam penanganan masalah perilaku siswa yang tidak dikehendaki konselor berperan sebagai konsultan, dimana konselor 
berkolaborasi dengan guru kelas dan guru mata pelajaran untuk membantu menangani perilaku siswa yang tidak dikehendaki.Adapun pendekatan yang digunakan dalam menangani perilaku siswa yang tidak dikehendaki adalah pendekatan modifikasi perilaku.

Ada beberapa jenis modifikasi perilaku dilihat dari landasan atau pijakan teorinya.Diantaranya adalah psikodinamik, medis, ekologis, dan behavioristik atau Analisis Tingkah Laku.Menurut Legowo keempat jenis tersebut disebut sebagai empat model modifikasi perilaku.Tidak semua jenis modifikasi perilaku cocok untuk diterapkan dalam bidang pendidikan.

Model Analisis Tingkah Laku (ATL) merupakan aplikasi dari teori behavioristik.Karena itu istilah Analisis Tingkah Laku sering disamakan dengan behavioristik.ATL sebagai teknik treatment lebih tepat digunakan di kelas.Menurut Legowo dalam penelitiannya tentang modifikasi perilaku antara lain menyimpulkan bahwa Analisis Tingkah Laku (ATL) memiliki peran yang sangat signifikan dalam mengubah perilaku siswa sekolah dasar yang tidak dikehendaki (off task behaviour).

Para ahli telah merinci tahapan prosedur melaksanakan ATL berbedabeda. Meskipun demikian dapat diambil persamaannya ada empat tahapan utama, yaitu :

a. Menetapkan perilaku yang akan diubah

Pada langkah awal melaksanakan Analisis Perilaku ada dua proses yang harus dilakukan. Pertama, mengidentifikasi satu perilaku yang akan dikurangi atau dihilangkan terjadinya (sebut perilaku Sasaran Deselerasi), kemudian juga menetapkan satu perilaku yang akan ditingkatkan terjadinya (sebut perilaku Sasaran Akselerasi). Baik perilaku Sasaran Akselerasi (SA) maupun perilaku Sasaran Deselerasi (SD) harus berupa satu jenis perilaku yang spesifik.Maksudnya, bahwa perilaku tersebut harus dapat diamati (observable) terjadinya, dapat diukur (measurable) dengan suatu instrumen tertentu, dan dapat dihitung (countable).Langkah selanjutnya adalah menghitung perilaku, menetapkan cara menghitungnya ada tiga cara mengukur dan menghitung sasaran perilaku, yaitu : sasaran, frekuensi, durasi dan latensi. Sasaran frekuensi dihitung dari keseringan muncul atau beberapa kali suatu perilaku itu muncul dalam periode waktu tertentu. Sasaran durasi dihitung dari lamanya perilaku terjadi di dalam periode waktu tertentu. Sasaran latensi dihitung dari jarak waktu antara ketika siswa diberi tugas atau perintah hingga ia melakukannya.

b. Mengases lingkungan saat perilaku muncul Lingkungan merupakan kejadian atau isyarat yang dapat berfungsi mengarahkan terjadinya perilaku (disebut dengan anteseden) dan juga dapat berfungsi melestarikan atau mereduksi perilaku tertentu (disebut konsekuen).

c. Merencanakan dan mengimplementasikan strategi pengubahan. Langkah ketiga dalam metode Analisis Perilaku adalah melakukan perencanaan strategi pengubahan..Ada dua poin yang harus dilakukan dalam merencanakan program 
pengubahan perilaku dengan metode Analisis Tingkah Laku.Dua poin tersebut adalah mendesain strategi Akselerasi (Strategi A) dan strategi Deselerasi (strategi D).

Strategi A merupakan strategi yang dirancang untuk mengajarkan keterampilan baru yang diperlukan siswa, sedangkan strategi D dirancang untuk tujuan mengurangi atau menghilangkan perilaku siswa yang tidak dikehendaki.

1) Diantara beberapa teknik kendali konsekuen yang sering digunakan untuk meningkatkan perilaku SA adalah reinforcement dan kontigensi kontrak. Reinforcement adalah suatu proses memperkuat sasaran perilaku yang dikehendaki dalam belajar, yaitu reinforcer material, token, aktivitas, sosial dan intrinsic.Wesley Becker memberikan empat aturan umum menggunakan reinforcement untuk meningkatkan belajar di dalam kelas Reinforcement harus segera diberikan sesudah perilaku terjadi, dan diberikan sesering mungkin.

2) Reinforcement hanya diberikan dalam interval setelah beberapa perilaku terjadi.

3) Reinforcement diberikan bergradasi dan tidak dapat diramalkan kapan diberikan walaupun perilaku baru telah dicapai. Pemberian reinforcement yang tak dapat diramalkan siswa dapat disamakan dengan bonus.
4) Yang paling penting yaitu memberikan reinforcement pada tahapan kecil perilaku terjadi. Ini merupakan cara yang efisien dalam mengarahkan perilaku yang dikehendaki.

Teknik untuk mereduksi perilaku yang lain adalah kontigensi kontrak. Kontigensi kontrak secara luas digunakan untuk meningkatkan perilaku klien.Teknik telah digunakan dengan hasil yang memuaskan untuk mengubah berbagai problem perilaku.Kontrak adalah suatu persetujuan, tertulis atau verbal.Antara dua orang atau lebih, individual atau kelompok, yang menetapkan tanggung jawab antara mereka tentang aktifitas atau item tertentu. Schloss \& Smith, dalam pandangan modifikasi perilaku, kontrak didefinisikan sebagai susunan kondisi yang memungkinkan anak dapat melakukan apa yang diinginkan, yang itu juga seseorang ingin ia melakukannya. Selanjutnya untuk keperluan pengubahan perilaku dalam Analisis Tingkah Laku, kontigensi kontrak didefinisikan sebagai deskripsi tertulis tentang hubungan antara perilaku siswa, perilaku guru, dan konsekuensi reinforcement. Kontigensi kontrak didasarkan pada prinsip yang menyatakan bahwa a behavior that has a hight rate of occurrence can be use to increase a behavior with a low rate of occurrence. Dalam menerapkannya teknik ini dikembangkan melalui proses 
negosiasi antara siswa, guru, atau orang lain yang terlibat di dalam program pengubahan perilaku.

$\begin{array}{rrr}\text { Agar } & \text { kontrak } & \begin{array}{r}\text { dapat } \\ \text { digunakan }\end{array} \\ \text { secara } & \text { efektif } \\ \text { hendaknya } & \text { melibatkan } & \text { siswa }\end{array}$
memutuskannya. Ada beberapa poin yang perlu diperhatikan dalam pelibatan siswa untuk sistem managemen kontrak, yaitu :

1) Pemilihan perilaku sasaran

2) Pemahaman terhadap perilaku khusus yang akan diubah

3) Pemilihan reinforcement

4) Mengevaluasi sistem tersebut dari sudut pandang siswa

Dalam Analisis Tingkah

Laku isyarat yang sering digunakan untuk mereduksi tingkah laku SD adalah hukuman (punishment) dan timeout.Pengertian punishment secara konseptual berbeda dengan yang dikemukakan orang pada umumnya. Schloss \&Smith (dalam Yusuf, 2007), secara konseptual punishment didefinisikan sebagai tereduksinya sasaran tingkah laku setelah kontigensi stimulus disajikan.

Goodwin \& Coates (dalam Yusuf, 2007) mengemukakan tiga resiko penggunaan punishment :

1) Pemberi punishment dapat menjadi model agresif bagi siswa. Karena siswa lebih mungkin melakukan apa yang dilakukan daripada apa yang dikatakannya.

2) Punishment sering mempunyai pengaruh menghasilkan reaksi emosi yang dalam yaitu dapat menghambat belajar siswa.

3) Yang paling penting punishment hanya mengatakan kepada individu tentang apa yang tidak boleh dilakukan.

Menurut Kazdin (dalam Yusuf, 2007), time-out juga sering digunakan untuk mereduksi perilaku sasaran deselerasi. Sedangkan menurut Walker \& Shea (dalam Yusuf, 2007) Time-out merupakan prosedur pengambilan reinforcement positif selama periode waktu tertentu Time-out dapat pula didefinisikan sebagai prosedur memindahkan anak dari tempat yang mereinforcemen ke tempat yang tidak reinforcement.Time-out hanya digunakan untuk tujuan managemen perilaku.

d. Mengevaluasi hasil.

Ada dua metode evaluasi pengubahan perilaku, yaitu : metode evaluasi kuantitatif dan kualitatif. Metode evaluasi kuantitatif adalah cara melakukan evaluasi dengan menggunakan ukuran-ukuran angka atau frekuensi. Dari angka atau frekuensi tersebut digunakan sebagai data dasar untuk proses analisis, interpretasi dan pengambilan kesimpulan. Sedangkan metode evaluasi kualitatif untuk menganalisis perubahan perilaku dapat dilakukan dengan mudah dan hasilnya lebih fungsional.

\section{METODE}

Jenis penelitian yang digunakan dalam penelitian ini adalah penelitian 
kualitatif deskriptif.Adapun alasan digunakan jenis penelitian ini karena peneliti ingin mendeskripsikan atau menggambarkan dengan kata-kata secara sistematis dan akurat mengenai fakta-fakta, sifat serta hubungan antara fenomena yang diteliti.menurut Donald Ary (2007:447) penyelidikan deskriptif adalah metode penelitian yang dirancang untuk memperoleh informasi tentang status gejala saat penelitian dilakukan.

Teknik pengambilan sampel
sumber data dilakukan secara purposiveyaitu berdasarkan rekomendasi dari guru BK yang mengidentifikasikan sebagai siswa yang memiliki permasalahan penyesuaian diri, teknik pengumpulan data dengan triangulasi sumber yaitu mendapatkan data dari sumber yang berbeda-beda dengan teknik yang sama. Dari data yang sudah ada yaitu dari konselor dan siswa, kemudian dideskripsikan dikategorikan, mana pandangan yang sama, yang berbeda, dan mana spesifik dari sumber data tersebut. Teknik pengumpulan data yang digunakan adalah

(1) obeservasi untuk mengetahui bentukbentuk perilaku siswa yang tidak dikehendaki dan penanganan konselor

(2) wawancara untuk menggali informasimengenai bentuk-bentuk perilaku siswa yang tidak dikehendaki, faktor-faktor penyebabnya, penanganan yang diberikan konselor untuk mmbantu menangani perilaku siswa yang tidak dikehendaki dan hambatan yang hadapi konselor dalam menangani masalah perilaku siswa yang tidak dikehendakidan (3) dokumentasi berupa data-data yang mendukung dalam penelitian.
Teknik analisis data pada penelitian kualitatif dilakukan sebelum penelitian, selama penelitian, dan setelah penelitian. Analisis data dilakukan secara berkelanjutan dan meliputi tiga alur, diantaranya adalah

(1) reduksi data, proses berpikir sensitif yang memerlukan kecerdasan dan keluasan dan kedalaman yang tinggi. Dalam reduksi data aktivitas berbentuk merangkum, memilih hal-hal yang pokok, memfokuskan pada hal-hal penting, yang dicari tema dan polanya, (2) penyajian data, dengan menyajikan data, maka akan memudahkan untuk memahami apa yang terjadi, merencakan kerja selanjutnya berdasarkan apa yang telah dipahami tersebut, (3) verifikasi atau kesimpulan, dalam hal ini diambil dari data yang terkumpul dan diverifikasi terus-menerus selama penelitian berlangsung agar data yang didapat terjamin keabsahan dan objektifitasnya, sehingga kesimpulan terakhir dapat dipertanggungjawabkan.

\section{HASIL TEMUAN}

\section{Wawancara}

Wawancara telah peniliti lakukan sesuai dengan produser yang telah peneliti jelaskan pada Bab III. Jumlah informan keseluruhan 13, yaitu 1 kepala sekolah, 2 konselor, 7 guru kelas dan 3 guru mata pelajaran. Wawancara dengan informan dilakukan secara terpisah. Hal ini peneliti lakukan untuk memperoleh informasi lebih mendalam. Berikut hasil wawancara yang dilakukan oleh peneliti :

a. Bentuk-bentuk perilaku off task Dari hasil wawancara yang dilakukan oleh peneliti bentukbentuk perilaku off task yang ditunjukkan oleh siswa SDIT Ash 
- Shidiiqi diantaranya membuat ramai atau gaduh, keluar masuk kelas, mengganggu atau menjaili temannya, tidak memperhatikan saat guru menerangkan, bermain sendiri, keliling atau keluyuran, ngobrol dengan siswa lain.

Kutipan wawancara yang dilakukan

peneliti :

Pertanyaan :"Bagaimana bentuk perilaku siswa yang tidak dikehendaki saat pembelajaran berlangsung ?"

Kepala Sekolah : "Ramai dan keluar-masuk kelas saat pembelajaran berlangsung."

Konselor : :Membuat gaduh, menjaili temannya, tidak memperhatikan saat guru menerangkan, bermain sendiri.

b. Faktor penyebab Dari hasil wawancara beberapa faktor yang menyebabkan siswa melakukan perilaku yang tidak dikehendaki adalah adaptasi sekolah, kurangnya perhatian dari guru, pengaruh dari teman, merasa bosan, merasa kesulitan dengan pelajaran.

Kutipan wawancara yang dilakukan peneliti adalah sebagai berikut:

$$
\begin{array}{ll}
\text { Pertanyaan } & : \text { Apa yang } \\
& \text { menyebabkan perilaku }
\end{array}
$$

tersebut terjadi ?"

Konselor :" Kesulitan dengan

pelajaran, dan pengaruh dari temannya."

c. Penanganan konselor
Berdasarkan hasil wawancara penanganan yang diberikan berupa diingatkan atau ditegur, diberi nasihat, diberi hukuman berupa pernyataan secara tertulis maupun hukuman lainnya, selain itu konselor juga berkolaborasi dengan guru kelas dan guru mata pelajaran menerapkan teknik penguatan (reinforcement) dan hukuman.

Berikut kutipan wawancara yang dilakukan oleh peneliti :

Pertanyaan : :Penanganan apa yang dilakukukan untuk menangani perilaku off task siswa ?"

Kepala Sekolah : “Diingatkan, lalu saya diskusikan dengan guru kelasnya terlebih dahulu agar anak tersebut sedikit diberi perhatian yang lebih, jika memang masih tidak ada perubahan saya minta bantuan konselor untuk menanganinya."

Konselor : :"Menegur, membimbing, diberi peringatan dengan membuat surat pernyataan, berkolaborasi dengan guru kelas dan guru mata pelajaran menerapkan teknik penguatan (reinforcement) dan hukuman."

d. Hambatan dalam penanganan Adapun hambatan yang ditemui dalam penanganan menurut hasil wawancara yg dilakukan oleh peneliti adalah keterbatasan pemberian layanan konseling secara langsung dan masih sulitnya mengontrol sikap anak usia SD.

Berikut kutipan wawancaranya : Pertanyaan :"Hambatan apa yang 
muncul ketika menangani perilaku siswa yang tidak dikehendaki ?"

Konselor :"Masih sulitnya mengontrol sikap anak usia SD."

Perilaku siswa yang tidak dikehendaki yang dilakukan siswa SDIT Ash - Shidiiqi Jambi cenderung memiliki kesamaan data antar informan yang menyatakan bahwa perilaku yang tidak dikehendaki yang dilakukan adalah membuat ramai atau gaduh, keluar masuk kelas mengganggu atau menjaili temannya, tidak memperhatikan saat guru menerangkan, bermain sendiri, keliling atau keluyuran, ngobrol dengan siswa lain. Beberapa faktor yang menyebabkan siswa melakukan perilaku yang tidak dikehendaki adalah adaptasi sekolah, kurangnya perhatian dari guru, pengaruh dari teman, merasa bosan, merasa kesulitan dengan pelajaran. Penanganan yang diberikan tidak memberikan perubahan yang signifikan terhadap perilaku siswa yang tidak dikehendaki. Hanya dengan diingatkan atau ditegur, diberi nasihat, diberi hukuman berupa pernyataan secara tertulis maupun hukuman lainnya, akan tetapi hal tersebut belum membuat siswa jera, selain itu konselor juga berkolaborasi dengan guru kelas dan guru mata pelajaran menerapkan teknik penguatan (reinforcement) dan hukuman. Karena memang dalam melakukan penanganan harus ada pemantauan secara berkala agar perilaku siswa dapat berubah. Selain itu karena ada hambatan pula seperti keterbatasan pemberian layanan konseling secara langsung dan masih sulitnya mengontrol sikap anak usia SD.

2. Observasi

Dalam penelitian ini, observasi yang digunakan adalah observasi pasif (passive participation). Peneliti sengaja menggunakan jenis observasi tersebut karena ingin mengetahui secara langsung perilaku apa saja yang dilakukan subyek tanpa terlibat dalam kegiatan tersebut. Namun hasil observasi tidak hanya berasal dari peneliti sendiri, akan tetapi juga berasal dari informan, karena keterbatasan waktu yang dimiliki oleh peneliti untuk terus berada di dalam lingkungan sekolah.

Sesuai dengan observasi yang telah dilakukan, maka diperoleh data bahwa bentuk perilaku siswa yang tidak dikehendaki yang sering terjadi adalah keliling, ngobrol dengan temannya, main alat tulis seperti rautan, penghapus, pensil, pulpen, atau penggaris, bercanda dengan temannya, mengganggu atau menjaili temannya, menggambar, mengajak temannya berbicara, mencoret-coret kertas, buku atau meja, membuka buku pelajaran lain, mengerjakan PR.

Faktor penyebab perilaku siswa yang tidak dikehendaki meliputi pengaruh teman dan kurang mendapat perhatian dari guru.

Penanganan yang dilakukan adalah ditegur atau diingatkan dengan diberi nasihat dan berkolaborasi dengan guru kelas menerapkan teknik penguatan (reinforcement) dan hukuman.

Hambatan yang dihadapi konselor ketika melakukan 
penanganan adalah tidak bisa memberikan konseling langsung kepada siswa, melainkan melalui guru kelas dan guru mata pelajaran.

3. Dokumentasi

Dalam penelitian ini, data dokumentasi difokuskan pada dokumentasi ketika melakukan penelitian. Dokumentasi dalam penelitian ini berupa foto atau gambar yang diambil ketika proses observasi dengan siswa.

Simpulan Triangulasi Sumber Data

Simpulan triangulasi ini bertujuan untuk merangkum jawaban dari masing-masing informan kemudian ditriangulasikan untuk mengetahui kejenuhan data. Data dikatakan jenuh jika masing-masing informan memiliki jawaban yang sama dalam satu pertanyaan. Jika dalam satu pertanyaan yang sama dan jawabannya pun sama antar informan maka data tersebut dapat dikatakan sudah jenuh. Sehingga data tersebut telah layak digunakan untuk penelitian.

Berikut ini disajikan mengenai triangulasi sumber dari beberapa informan penelitian :

\begin{tabular}{|c|c|c|c|}
\hline \multirow{2}{*}{ Aspek } & \multicolumn{3}{|c|}{ Sumber Data } \\
\hline & Konselor & Guru & $\begin{array}{l}\text { Kepala } \\
\text { Sekolah }\end{array}$ \\
\hline $\begin{array}{l}\text { Be } \\
\text { ntu } \\
\text { k } \\
\text { per } \\
\text { ila } \\
\text { ku }\end{array}$ & $\begin{array}{l}\text { Membuat } \\
\text { gaduh, } \\
\text { menjaili } \\
\text { temannya, } \\
\text { tidak } \\
\text { memperha } \\
\text { tik an saat } \\
\text { guru }\end{array}$ & $\begin{array}{l}\text { Muter- } \\
\text { muter, } \\
\text { tidak } \\
\text { memperha } \\
\text { ti kan saat } \\
\text { guru } \\
\text { menerang } \\
\text { ka n, }\end{array}$ & $\begin{array}{l}\text { Ramaida } \\
\mathrm{n} \text { keluar } \\
\text { masuk } \\
\text { kelas } \\
\text { saat } \\
\text { pembela } \\
\text { jara n } \\
\text { berlangs }\end{array}$ \\
\hline
\end{tabular}

\begin{tabular}{|c|c|c|c|}
\hline & $\begin{array}{l}\text { menerang } \\
\text { ka } \\
\text { n, bermain } \\
\text { sendiri, } \\
\text { muter- } \\
\text { muter } \\
\text { didalam } \\
\text { kelas, } \\
\text { keluar- } \\
\text { masuk } \\
\text { kelas, } \\
\text { menggang } \\
\text { gu siswa } \\
\text { lain. }\end{array}$ & $\begin{array}{l}\text { menggang } \\
\text { gu } \\
\text { temannya, } \\
\text { membuat } \\
\text { gaduh, } \\
\text { keluar- } \\
\text { masuk } \\
\text { kelas, } \\
\text { ramai saat } \\
\text { dijelaskan, } \\
\text { bermain } \\
\text { sendiri, } \\
\text { usil } \\
\text { kepada } \\
\text { temannya, } \\
\text { ngoberol } \\
\text { dengan } \\
\text { siswa lain, } \\
\text { Tidak bisa } \\
\text { diam. }\end{array}$ & ung \\
\hline $\begin{array}{l}\text { Fakto } \\
\text { r } \\
\text { penye } \\
\text { bab }\end{array}$ & $\begin{array}{l}\text { Kesulitan } \\
\text { dengan } \\
\text { pelajaran, } \\
\text { pengaruh } \\
\text { dari } \\
\text { temannya, } \\
\text { adaptasi } \\
\text { sekolah, } \\
\text { kurangnya }\end{array}$ & & \\
\hline
\end{tabular}

Simpulan triangulasi ini bertujuan untuk merangkum jawaban dari masing-masing informan kemudian ditriangulasikan untuk mengetahui kejenuhan data. Data dikatakan jenuh jika masing-masing informan memiliki jawaban yang sama dalam satu pertanyaan. Jika dalam satu pertanyaan yang sama dan jawabannya pun sama antar informan maka data tersebut dapat dikatakan sudah jenuh. Sehingga data tersebut telah layak digunakan untuk penelitian. 


\section{Pembahasan}

Salah satu tugas perkembangan anak usia sekolah dasar antara umur 6 sampai 12 tahun adalah mengembangkan kemampuan bekerja keras dan menghindari perasaan rendah diri. Saat anak-anak pada usia ini area sosialnya bertambah luas dari lingkungan keluarga merambah sampai ke sekolah, sehingga semua aspek harus memiliki peran, misalnya orang tua harus selalu mendoreong, guru harus memberi perhatian, teman harus menerima kehadirannya, dan lain sebagainya. Usia ini menunjukkan adanya pengembangan anak terhadap rencana yang pada awalnya hanya sebuah fantasi berkembang menjadi rencana yang ada harus dapat diwujudkan yaitu untuk dapat berhasil dalam belajar.

Setiap siswa datang ke sekolah dengan harapan agar bisa mengikuti pendidikan dengan baik dan mencapai keberhasilan dalam belajar, akan tetapi tidak selamanya demikian. Ada beberapa jenis masalah belajar yang mengembangkan konsentrasi dalam mengerjakan sesuatu termasuk memperhatikan penjelasan dari guru, mengerjakan tugas, dan lain sebagainya. Selain adaptasi sekolah, kesilitan dalam pelajaran juga menjadi hal yang mendorong siswa melakukan perilaku yang tidak dikehendaki karena siswa cenderung merasa bosan dan melakukan hal lain yang dianggap menyenangkan serta dapat mengganggu konsentrasi belakar siswa. Faktor eksternal yang mendasari munculnya perilaku siswa yang tidak dikehendaki yaitu pengaruh dari teman dan kurangnya perhatian dari guru. Bagi siswa SD diterima dan menjadi anggota kelompok merupakan hal yang penting, karena pada usia ini mereka membentuk persahabatan dan cenderung melihat kelompok mereka sebagai model tingkah laku, pemberi dukungan moral dan social reinforcement seperti yang mereka lihat pada keluarga mereka sendiri. Kurangnya perhatian dari guru juga salah satu penyebab perilaku off task yang dilakukan oleh siswa karena selain menyampaikan ilmu pengetahuan guru juga dapat menilai dan mengoreksi semua hasil belajar, sikap, tingkah laku dan perbuatan siswa. Jika perhatian yang diberikan oleh guru kurang, maka akan berdampak pada perilaku siswa. Penelitian Saputri, Prayitno \& Jaya (2018) menyatakan bahwa penanganan mahasalah siswa di sekolah butuh pembinaan khusus bagi konselor.

Penanganan yang dilakukan oleh konselor sekolah yaitu menegur atau mengingatkan dengan memberi nasihat, memberi hukuman berupa pernyataan tertulis atau hukuman lain yang mendidik dan tidak memberatkan, hal itu dilakukan untuk memberi efek jera supaya siswa tidak mengulangi perilaku off task. Selain itu untuk menangani perilaku off task siswa konselor berkolaborasi dengan guru kelas dan guru mata pelajaran menerapkan teori behavioristik dari B.F. Skinner yaitu operan conditioning (pengkondisian operan) dengan menggunakan teknik penguatan (reinforcement) dan hukuman. Penguatan diberikan seiring munculnya perilaku yang diharapkan. Adapun penguatan yang diberikan berupa penguatan positif dan penguatan negatif. Penguatan positif dilakukan dengan cara 
memberikan sesuatu yang menyenangkan, berupa hadiah (permen atau snack), perilaku (bertepuk tangfan atau mengacungkan jempol), atau penghargaan (menambah point). Sedangkan penguatan negatif dilakukan dengan cara mengambil atau mengurangi sesuatu yang membebani atau tidak menyenangkan, berupa membebaskan atau mengurangi tugas yang harus diselesaikan. Baik penguatan positif maupun negatif keduanya memberikan efek menyenangkan sehingga cenderung memperkuat atau mempertahankan perilaku yang diharapkan. Selain menggunakan teknik penguatan (reinforcement), teknik yang digunakan adalah hukuman. Hukuman digunakan utnk menurangi atau menghentikan perilaku yang tidak diharapkan. Hukuman yang diberikan antara lain reprimand, response cost, dan time out. Reprimand merupakan bentuk ekspresi ketidaksetujuan. Response- cost diberikan dengan cara mengambil penguat atau sebagian dari penguat setelah munculnya perilaku yang tidak diharapka, seperti mengurangi point karena telah membuat keributan selama pembelajaran berlangsung. Sedangkan time-out bentuk hukuman yang diberikan secara temporer mengikuti perilaku tidak adaptif, seperti guru menunda memberikan materi selama lima menit karena siswa ramai.

Terdapat perbedaan penting yaitu beberapa jenis layanan bimbingan tidak dapat langsung diberikan kepada siswa, melainkan diluncurkan melalui guru, orang tua dan orang dewasa lainnya karena siswa SD memiliki keterbatasan dalam menerima tanggung jawab dirinya, selain itu layanan bimbingan dan konseling di SD kurang menekankan pada penyimpanan data, testing, perencanaan pendidikan, pendekatan yang berorientasi pada pemecahan ,masalah dan konseling atau terapi individual.

Hambatan yang dihadapi konselor, yaitu masih sulitnya mengontrol sikap anak usia SD, dimana anak pada usia ini belum memiliki keajegan dan masih butuh bantuan dari orang dewasa seperti guru dan orang tua, berbeda halnya dengan anak usia remaja yang dapat lebih stabil untuk menyesuaikan diri dan mulai membuat keputusan tentang tingkah lakunya.

\section{SIMPULAN}

Dari analisis data dan pembahasan pada bab sebelumnya, maka dapat disimpulkan bahwa hasil penelitian ini menunjukkan bentuk perilaku off task siswa SDIT Ash Shidiiqi Jambi yaitu keliling, ngobrol dengan temannya, naik ke atas kursi, keluar masuk kelas, bercanda dengan temannya, mengajak temannya berbicara, menggambar, mencoret-coret kertas, buku atau meja, meletakkan kepala di atas meja, membuka buku pelajaran lain, mengerjakan PR, bermain alat tulis seperti pensil, pulpen, penghapus atau penggaris, bermain atau melempas kertas.

Penyebab perilaku off task siswa SDIT Ash - Shidiiqi Jambi terdiri dari faktor internal dan faktor eksternal.Faktor internal meliputi adaptasi sekolah dan kesulitan dalam pelajaran.Sedangkan faktor eksternal yang mendasari perilaku off task siswa 
adalah pengaruh dari teman dan kurangnya perhatian dari guru.

Penanganan yang dilakukan konselor dalam menangani perilaku off task siswa yaitu menegur atau mengingatkan dengan memberi nasihat, memberi hukuman berupa pernyataan tertulis atau hukuman lain yang mendidik dan tidak memberatkan, selain itu untuk menangani perilaku off task siswa konselor berkolaborasi dengan guru kelas dan guru mata pelajaran menerapkan teori behavioristik dari B.F. Skinner yaitu operan conditioning (pengkondisian operan) dengan menggunakan teknik penguatan (reinforcement) baik penguatan positif dan negatif untuk mempertahankan perilaku yang diharapkan, dan teknik hukuman untuk mengurangi atau menghentikan perilaku yang tidak diharapkan.

Sedangkan hambatan yang dihadapi oleh konselor dalam menangani perilaku off task siswa yaitu masih sulitnya mengontrol sikap siswa SD, dimana siswa pada masa ini belum memiliki keajegan dan masih butuh bantuan dari orang dewasa seperti guru dan orang tua.

\section{DAFTAR PUSTAKA}

Arikunto, Suharsimi. 2009. Manajemen Penelitian. Jakarta : Rineka Cipta

Asmani, Jamal Ma'mur. 2010. Panduan Efektif Bimbingan dan Konseling di Sekolah.Jogjakarta : Divapress

Austin, Jennifer L \& Soeda, Jennifer M. 2008.Fixed Time Teacher Attention
Decrease Off Task Behaviors of Typically Developing Third Grades. (Online) (austin@uhcl.edu, diakses 3 Mei 2013)

Baker., R. S. J. Modelling and Understanding Student Off Task Behavior in Intellegent Tutoring System. (Online) (ryan@educationaldatamining.org, diakses 3 Mei 2013)

Darminto, Eko. 2009. Teori-teori Konseling. Jambi : Unesa University Press

Eka Puspitaningsih, Ratih. 2010. Keefektifan Teknik Self Monitoring dan Self Reinforcement untuk Mengurangi Perilaku Off Task Siswa SMP Negeri 20 Malang. Skripsi. (Tidak Diterbitkan)

Harmiyanto. 2012. Efektivitas Teknik Stop and Think untuk Menurunkan Perilaku Off Task dalam Pembelajaran Matematika di SD. Malang

:Universitas Negeri Malang. Tesis. (Tidak Diterbitkan)

Hulac, David M \& Nicholas Benson. 2011. Getting Students to Work Smarter and Harder : Decreasing Off Task Behavior Through Interpersa Techniques. (Online) (david.hulac@usd.edu, diakses 3 Mei 2013)

Kartadinata, Sunaryo. dkk. 2007. Ramburambu Penyelenggaraan Bimbingan dan Konseling dalam Jalur Pendidikan Formal. Jakarta : Direktorat Jenderal Peningkatan Mutu Pendidikan dan Tenaga 
Kependidikan Departemen Pendidikan Nasional

Kercood, Suneeta Et Al. 2009.The Effects of Highlighting on the Math Compulation Performance and Off Task Behavior of Students with Attention. (Online) (skercood@butler.edu, diakses 3 Mei 2013)

Naqiyah, Najlatun. 2013. Bimbingan dan Konseling Komunitas. Jambi : Unesa University Press

Prayitno dan Erman Amti. 2004. Dasardasar Bimbingan dan Konseling. Jakarta : Rineka Cipta.

Saputri, S. M., Prayitno, P., \& Jaya, Y. (2018). KINERJA GURU BIMBINGAN DAN KONSELING SERTA PEMBINAANNYA. ENLIGHTEN: Jurnal Bimbingan Konseling Islam, 1(1), 1-20. https://doi.org/10.32505/enlighten. v1i1.511

Sugihartono, dkk. 2007. Psikologi Pendidikan. Yogyakarta : UNY Press

Sugiyono. 2013. Memahami Penelitian Kualitatif.Bandung : Alfabeta

Tim Penyusun. 2014. Pedoman Penulisan Skripsi Unesa. Jambi : Unesa

Walgito, Bimo. 2005. Bimbingan dan Konseling (Studi dan Karir). Yogyakarta : ANDI

Wardah, Ani. 2010. Pengembangan Cerita Bergambar untuk Mengubah Tingkah Laku Off Task Siswa Sekolah Dasar. Malang :
Universitas Negeri Malang. Tesis. (Tidak Diterbitkan)

Yusuf, Munawir dan Edy Legowo. 2007. Mengatasi Kebiasaan Buruk Anak dalam Belajar Melalui Pendekatan Modifikasi Perilaku.Jakarta : Departemen Pendidikan Nasional 